\title{
Jornalismo, Rádio e Inovação
}

esta edição, a segunda de 2020, a revista Estudos em Jornalismo
e Mídia (EJM) oferece a seus leitores um dossiê especial que co-
labora para o avanço da pesquisa na área dos estudos radiofôni-
cos, neste período em que o rádio completa 100 anos de história.
O dossiê 100 anos de Metamorfose - Rádio e Inovação foi coordenado pelas professoras Valci Zuculoto (PPGJOR/UFSC) e Débora Lopez (UFOP) e pelo professor Marcelo Kischinhevsky (UFRJ/UERJ). Na apresentação Para além das efemérides, um convite a pensar o rádio, os três professores-pesquisadores expõem os 11 artigos que integram o dossiê temático.

Além desses 11 trabalhos, a presente edição da EJM traz ainda nove artigos da seção Temas Livres. Os artigos desta seção abordam temas diversos acerca do jornalismo, assessoria de imprensa e fotojornalismo. O primeiro da seção Temas Livres e $12^{\circ}$ da presente edição, de autoria de Andriolli Costa, aborda as transformações no imaginário do Jornalismo na passagem do período industrial para o pós-industrial. Como explicita o autor, a análise que as imagens presentes no imaginário do jornalismo "são dinamizadas a partir de suas respostas imaginantes a pulsões ancestrais: Mitos do Tempo, Mitos Especulares, Mitos do Progresso e Mitos da Ordem".

No $13^{\circ}$ artigo desta edição da EJM, Rafael Rangel Winch e Daiane Bertasso discutem o modo como o discurso jornalístico valora as vozes das fontes de classes populares, concedendo e interditando determinadas posições para esses sujeitos. Eles analisam uma reportagem televisiva do programa Caminhos da Reportagem (TV Brasil) e mostram que o discurso jornalístico situa as vozes das fontes de classes populares em posições de descrição, lamentação e ilustração, em detrimento de posições de opinião, saber e proposição.

Cíntia Liesenberg e Nara Lya Cabral Scabin, co-autoras do $14^{\circ}$ artigo da edição, também estão interessadas no discurso jornalístico em sua relação com a alteridade. modo como dois jornais considerados de referência (Folha de S. Paulo e $O$ Estado de S. Paulo) tratam a alteridade. As pesquisadoras analisam as mediações jornalísticas efetuadas por esses dois periódicos sobre a operação realizada pelas polícias Civil e Militar de São Paulo, em maio de 2017, na região conhecida como "Cracolândia" de São Paulo, buscando apreender as representações de alteridade que são construídas e discutir as (in)visibilidades conferidas ao outro.

Na sequência, Verônica Soares da Costa e Luana Teixeira de Souza Cruz analisam textualidades produzidas e distribuídas sobre o tema das vacinas pelos sites dos jornais nativos digitais Nexo e Vox, objetivando identificar se e como ocorre a circulação da temática nesses dois veículos. A partir da análise do fluxo de informações, elas indicam a existência de uma relação textual entre os fenômenos da vacinação e do movimento 
antivacinação, classificado como um novo tipo de controvérsia midiatizada.

Alexandre Lenzi, que assina o $16^{\circ}$ desta edição da $E J M$, também toma o jornal digital Nexo como objeto empírico para analisar as características das reportagens multimídia produzidas por esta mídia.

Ana Taís Martins assina o $17^{\circ}$ artigo, intitulado Desafios do ensino do fotojornalismo na cultura digital. Seu trabalho descreve mudanças no processo de ensino-aprendizagem de fotojornalismo, desde a transição das técnicas analógicas até a consolidação da tecnologia digital. Entre as conclusões, aponta que, para além dos constantes desafios técnicos, o ensino do fotojornalismo traz sobretudo desafios éticos, com a complexificação de conceitos como o de verdade e autoria no atual contexto de cultura digital.

O $18^{\circ}$ artigo, assinado por Aline Louize Deliberali Rosso, aborda a assessoria de imprensa no campo da política, buscando identificar como jornalistas assessores de imprensa que trabalham na Assembleia Legislativa do Estado de Santa Catarina caracterizam sua atuação fora dos meios de comunicação. Conforme o estudo, tal caracterização refere a atuação em assessorias como um trabalho com atributos próprios e, simultaneamente, com características do campo jornalístico.

No penúltimo artigo da edição, Jorge Kanehide Ijuim e Cândida de Oliveira discutem o papel do jornalismo no processo de judicialização da política e as relações entre imprensa e judiciário na formação de consensos e da percepção sobre a política. Partem do caso da operação Lava Jato, que ganhou projeção na mídia e na sociedade brasileira desde 2014 a partir de controversas ações de combate à corrupção, para problematizar a noção de "quarto poder" e das relações da imprensa com fontes de informação. Já Edson Dalmonte e Caio Cardoso de Queiroz que assinam o $20^{\circ}$ e último artigo desta edição da revista: A vigilância como prática e valor jornalístico na cobertura da \#VazaJato. Os pesquisadores analisam, em textos de oito mídias jornalísticas, o caso do famoso escândalo de vazamento de diálogos entre integrantes da Lava Jato, que veio a público através de reportagens do The Intercept Brasil. Mostram que, no transcurso da cobertura, as ações de monitoramento, acompanhamento e crítica sobre as esferas de poder são vistas como definidoras de um dever jornalístico. E observam que a dinâmica de discussão de padrões morais na profissão reforça a vigilância como aspecto central nas formas de justificação do jornalismo.

Para esta edição da EJM, que foi produzida no contexto de um acontecimento que afetou o mundo em 2020 - a pandemia de Covid-19 -, Andressa Kikuti, Dairan Paul e Suelyn Luz, doutorandos do PPGJOR/UFSC, entrevistaram a pesquisadora chilena, Claudia Mellado Ruiz, professora e chefe de investigação na Escola de Jornalismo da Universidade Católica de Valparaíso (Chile). Ela é referência em pesquisas comparadas na área e atualmente coordena duas pesquisas internacionais, ambas envolvendo o Brasil: a Journalistic Role Performance (JRP) e a JRP-COVID. Na entrevista à EJM, ela aborda os desafios e avanços dos estudos comparados internacionais, explica as pesquisas do JRP e discute a influência do contexto político-econômico nas pesquisas das áreas de Humanas e Sociais.

Duas resenhas encerram a edição. Na primeira delas, Kérley Winques compartilha com os leitores da revista a sua leitura do livro A construção mediada da realidade, de Nick Couldry e Andreas Hepp (2020). Na segunda, Marcionize Bavaresco expõe sua síntese e reflexões do livro Democracy without Journalism? Confronting the Misinformation Society, de Victor Pickard (2020).

Para concluir a apresentação da nova edição da revista, agradecemos a participação das professoras Valci Zuculoto e Débora Lopez e do professor Marcelo 
Kischinhevsky, que coordenaram a edição do dossiê especial 100 anos de Metamorfose - Rádio e Inovação e que o apresentam aqui na sequência. Agradecemos também a autoras e autores que assinam os artigos publicados nesta edição, bem como o trabalho fundamental realizado por avaliadores(as), revisores(as) e pela diagramadora da revista EJM.

Desejamos uma boa leitura!

Terezinha Silva e Flávia Guidotti 